Mycopathologia vol. 64, 2: 67-72

\title{
FUNGI IN LIBRARIES: AN AEROMETRIC SURVEY*
}

\author{
H. P. BURGE**, J. R. BOISE, W. R. SOLOMON \& E. BANDERA
}

University of Michigan Medical School, R6621 Kresge Medical Research Building-1, Ann Arbor, Mich. 48109, USA

\begin{abstract}
The possible role of fungi as allergic contaminants in book collections has been investigated in eleven University of Michigan Libraries. Air in the stacks of each of the eleven libraries was sampled on three occasions ( 2 or 4-10 minute samples on each occasion) with Andersen Volumetric viable particle samplers. Books were handled during sampling in half the samples each day. In addition on each sampling day a location in the same building away from book storage and an outdoor location were sampled. Library spore levels were generally low. Outdoor levels consistently exceeded indoor levels. Air conditioned (AC) libraries had lower spore levels and indoor/outdoor ratios than conventionally ventilated (CV) libraries. Handling books during sampling increased spore counts in all libraries, but strikingly in $\mathrm{CV}$ libraries. Fungus taxa recovered were similar to those encountered in domestic interiors and outside locations in our area. The overall low spore levels and lack of a distinctive library mycoflora suggest that other sources should be sought for librarybased respiratory symptoms.
\end{abstract}

The occurrence of rhinitis or asthma provoked by exposure to libraries and other book collections is well documented (1). While variously ascribed to house dust, arthropods and bindery glues, this symptom pattern generally defies explanation. In this climate of uncertainty, the possible role of fungi as allergenic contaminants of book collections arises naturally for consideration. Among enclosed snaces libraries offer unique substrate characteristics while generally excluding factors (e.g., animal danders and food fragments) present in domestic dusts. Faced with patients describing respiratory symptoms with library use, we have

* Supported by Research Grant A1-10181 from the National Institutes, of Health, USPHS.

** Reprint requests to Harriet P. Burge, Ph. D., at the above address. initiated study of the mycoflora of these specialized interiors.

\section{Materials and methods}

All air sampling was done with an Andersen model 0101 sampler (Andersen 2000 Inc., Atlanta, Ga.) (2) calibrated to draw one cubic foot (28.3 liters)/min over a single agar plate beneath the sixth stage (7). Malt extract agar (32 g malt extract, $16 \mathrm{~g}$ agar, $1 \mathrm{~g}$ yeast extract, $1000 \mathrm{ml}$ distilled water) was used for most indoor and all outdoor sampling. Filter paper agar ( $30 \mathrm{~g}$ filter paper disrupted in a blender with $500 \mathrm{ml}$ distilled water, $16 \mathrm{~g}$ agar, $500 \mathrm{ml}$ additional distilled water) was used for one activity-related sample in each library to facilitate isolation of cellulose-utilizing fungi. Sampling periods varied from 0.5 minutes in outside air at midsummer to 10 minutes for most of the indoor work. Collections were made in the period from July 1974 to March 1975.

Samples were obtained at two sites in each of eleven University of Michigan libraries. The libraries are listed in Table 1 with relevant data on their physical plants and circulation figures. These locations were chosen to provide variety in types, numbers, and ages of books; use levels; and the presence or absence of air conditioning. Collections were made with the sampler upright on a chair approximately 18 inches above the floor. Initially three sequential samples were taken: one (malt agar) without added site disturbance, two with activity (books were removed from the shelves by two people, paged through, then reshelved during sampler operation); one of these 'activity' samples used malt agar, one filter paper agar. During the winter months, two samplers were available and were operated simultaneously, as above except that malt agar was used in both samplers and paper agar sampling was discontinued. Also during the winter, a location away from book storage (i.e., hallway, staff room) was sampled 


\begin{tabular}{|c|c|c|c|c|}
\hline Gibrary & $\begin{array}{l}\text { Year Con- } \\
\text { structed }\end{array}$ & $\begin{array}{l}\text { Book Circu- } \\
\text { lation } \\
1973 / 74\end{array}$ & Cooling system & Notes \\
\hline $\begin{array}{l}\text { Bureau of } \\
\text { Government }\end{array}$ & 1938 & 5,901 & Floor fans & $\begin{array}{l}\text { Basement library; books shelved } \\
\text { under leaky pipes }\end{array}$ \\
\hline Chemistry & 1908 & 14,962 & $\begin{array}{l}\text { Open windows } \\
\text { Floor fans }\end{array}$ & \\
\hline Ius eums & 1928 & 16,617 & $\begin{array}{l}\text { Open windows } \\
\text { Floor fans }\end{array}$ & \\
\hline $\begin{array}{l}\text { Jatural } \\
\text { Science }\end{array}$ & 1915 & 38,907 & $\begin{array}{l}\text { Open windows } \\
\text { Floor fans }\end{array}$ & \\
\hline lements & 1923 & None & Air conditioned & $\begin{array}{l}\text { Air conditioning added; windows } \\
\text { open; rare books housed in locked } \\
\text { glass cases }\end{array}$ \\
\hline Ierbarium & 1914 & $\begin{array}{l}\text { Reported by } \\
\text { Museum }\end{array}$ & Air conditioned & $\begin{array}{l}\text { Air conditioning added; no win- } \\
\text { dows directly to outside }\end{array}$ \\
\hline $\begin{array}{l}\text { Ing. and } \\
\text { Trans. }\end{array}$ & 1957 & 36,088 & Air conditioned & $\begin{array}{l}\text { Major AC breakdown summer } 1974 \text {; } \\
\text { only a few small windows open }\end{array}$ \\
\hline $\begin{array}{l}\text { ibrary } \\
\text { ext. service }\end{array}$ & 1954 & 5,800 & Air conditioned & $\begin{array}{l}\text { Major AC breakdown summer } 1974 ; \\
\text { floor fans and open windows } \\
\text { during repairs }\end{array}$ \\
\hline $\begin{array}{l}\text { Institute of } \\
\text { Sci. \& Tech. }\end{array}$ & 1964 & $\begin{array}{l}\text { Reported by } \\
\text { Phoenix }\end{array}$ & Air conditioned & \\
\hline hoenix & 1955 & 8,232 & Air conditioned & $\begin{array}{l}\text { Joined lst winter } 1975 \text {, moving } \\
\text { in progress during sampling }\end{array}$ \\
\hline blic & 1971 & 41,230 & Air conditioned & \\
\hline
\end{tabular}

using the two samplers operating simultaneously. Each library was sampled on three occasions (two during July, Aug. or Sept. and once during Dec., Jan. or Feb.) except Phoenix (twice) and North Engineering (once). This resulted in 30 sampling occasions, 150 library sample plates, 42 hallway samples and 33 outdoor samples. All resulting samples were incubated at room temperature for seven days after which each plate was quantitatively evaluated. Cladosporium and Aspergillus were identified to the species level using Ellis (4) and Raper (5) respectively; all other filamentous mold colonies were identified to genera only. Yeasts were identified only as such. All counts were converted to spores $/ \mathbf{M}^{3}$. Summer samples were taken when the mean overnight temperature exceeded $55^{\circ} \mathrm{F}$. Winter samples were taken on days with at least 1 inch of snow cover.

An outdoor sample was taken on each library sampling half day-i.e., a morning outdoor sample accompanied a set of morning library samples. The wind-oriented samples 
were taken on the roof of the Kresge Medical Research Building 50 feet above grade in Ann Arbor. This building is part of the medical center, approximately midway between central campus ( 7 libraries) and north campus ( 3 libraries). Public Health is part of the medical center. All libraries were within a one mile radius of the Kresge Building.

The Andersen sampler recovers viable reproductive units of microorganisms which include sexual and asexual spores and hyphae fragments. For convenience the term spore will be used to designate all recoveries.

\section{Results}

Maximum spore levels encountered in the eleven libraries with sameday outdoor levels are presented in Table 2. Outdoor levels consistently exceeded indoor levels (before disturbance) except in the Museums library. Degrees of difference between indoor and outdoor counts as indicated

\begin{tabular}{|c|c|c|c|c|c|c|}
\hline & & Surmer & & & Winter & \\
\hline & $\begin{array}{c}\text { Non- } \\
\text { Activity }\end{array}$ & Activity & Outside & $\begin{array}{c}\text { Non- } \\
\text { Activity }\end{array}$ & Activity & Outside \\
\hline $\begin{array}{l}\text { Eureau of } \\
\text { Government }\end{array}$ & 142 & 494 & 1024 & 7 & 50 & 78 \\
\hline Chemistry & 339 & 918 & 530 & 18 & 187 & 35 \\
\hline Museums & 539 & 636 & 1014 & 32 & 35 & 21 \\
\hline $\begin{array}{l}\text { Natural } \\
\text { Science }\end{array}$ & 442 & 636 & 636 & 25 & 127 & 85 \\
\hline Clements & 85 & 120 & 1271 & 173 & 403 & 410 \\
\hline Herbarium & 219 & 1059 & 1369 & 21 & 32 & 117 \\
\hline $\begin{array}{l}\text { Eng. } \\
\text { Transport. }\end{array}$ & 95 & 106 & 723 & 0 & 18 & 92 \\
\hline $\begin{array}{l}\text { Library } \\
\text { Extension }\end{array}$ & 78 & 220 & 777 & $a$ & 67 & 412 \\
\hline $\begin{array}{l}\text { Inst. Sci. } \\
\text { Tech. }\end{array}$ & & & & 28 & 39 & 124 \\
\hline Phoenix & 699 & 883 & 5156 & & & \\
\hline $\begin{array}{l}\text { Publ ic } \\
\text { Heal th }\end{array}$ & 10 & 71 & 2260 & 4 & 14 & 28 \\
\hline
\end{tabular}

Table 4. Activity/non-activity ratios for the categories

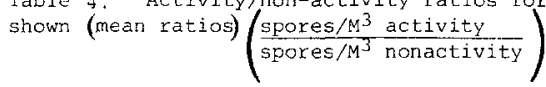

$\begin{array}{lccc} & \begin{array}{c}\text { Air } \\ \text { Conditioned }\end{array} & \text { Air Conditioned } & \text { Overail } \\ \text { Sunmer } & 1.6 & 2.7 & 2.1 \\ \text { Winter } & 1.9 & 3.8 & 2.8 \\ \text { Year round } & 1.8 & 3.3 & 2.4\end{array}$

Table 5. Fxequency of recovery (total plates) of the 20 taxa recovered on 2 or more plates.

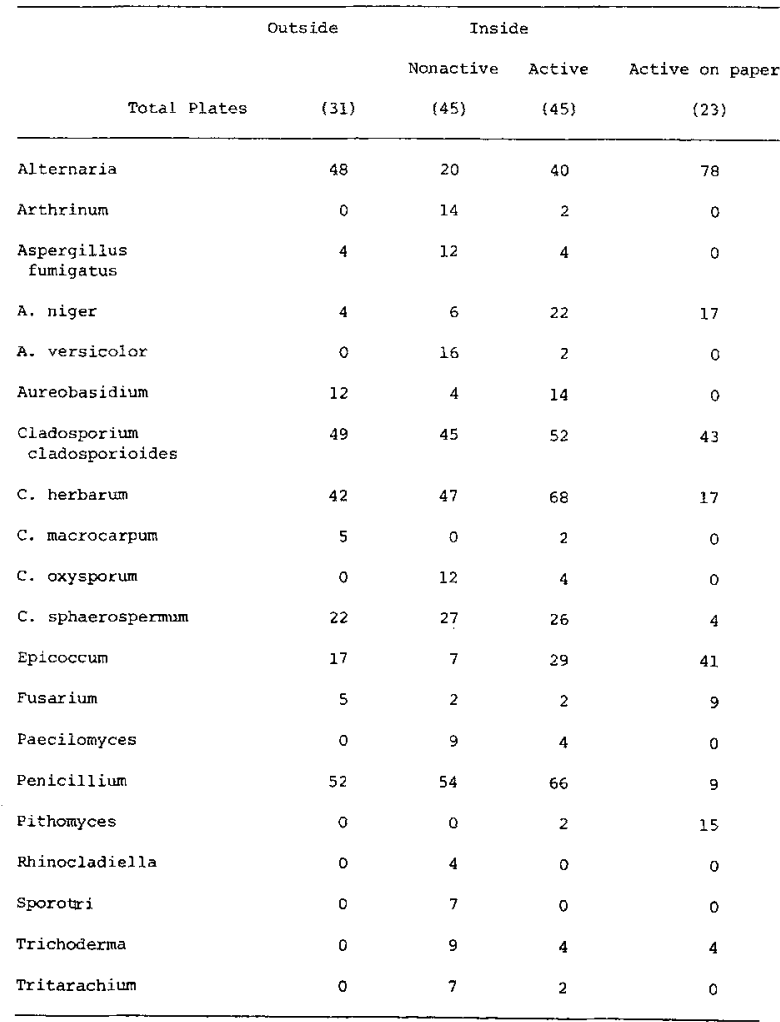
Table 3. Indoor/outdoor viable fungus spore ratios $\left(\frac{s p o r e s / M^{3} \text { indoors }}{s p o r e s / M^{3} \text { outdoors }}\right)$; $\mathrm{palues}$
represent sign test comparisons of sane day samples.

\begin{tabular}{|c|c|c|c|c|c|c|}
\hline & $\begin{array}{c}\text { Means for all } \\
\text { libraries }\end{array}$ & $\begin{array}{c}\text { Sign test } \\
\mathrm{p}<\end{array}$ & $\begin{array}{l}\text { Means for } \\
\text { AC libr. }\end{array}$ & $\begin{array}{c}\text { Sign test } \\
p<\end{array}$ & $\begin{array}{l}\text { Means for Non } \\
\text { AC libraries }\end{array}$ & $\begin{array}{c}\text { Sign test } \\
p<\end{array}$ \\
\hline $\begin{array}{l}\text { Year round } \\
\text { nonactivity }\end{array}$ & 0.36 & 0.01 & 0.22 & 0.01 & 0.52 & 0.01 \\
\hline $\begin{array}{l}\text { Summer non- } \\
\text { activity }\end{array}$ & 0.19 & 0.01 & 0.06 & 0.01 & 0.32 & 0.01 \\
\hline winter non- & 0.43 & 0.01 & 0.33 & 0.01 & 0.57 & ns \\
\hline
\end{tabular}


Table 6. Mean spores $/ \mathrm{M}^{3} \pm$ standard deviations of 14 taxa recovered on 5 or more plates.

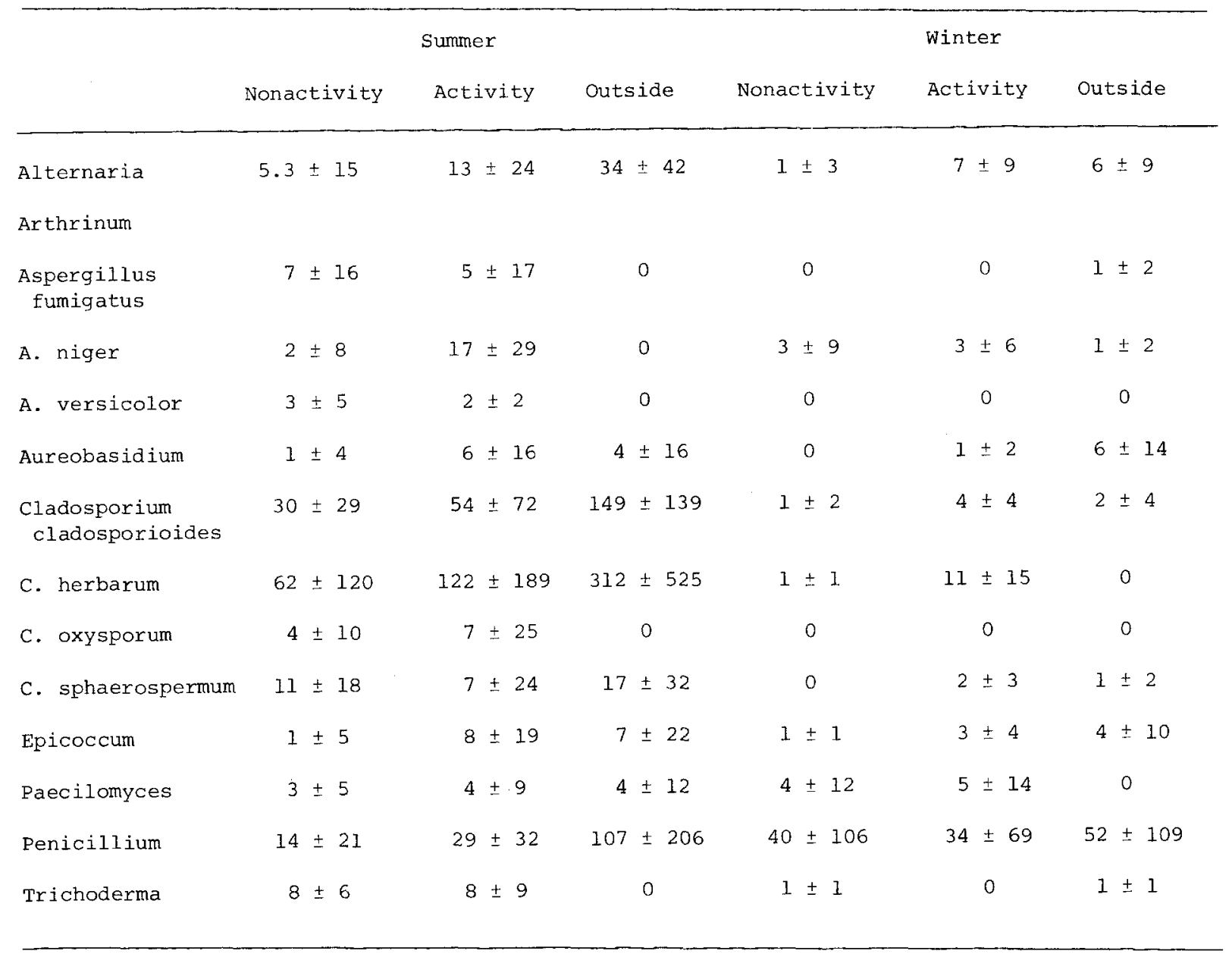

by indoor/outdoor ratios are displayed in Table 3. Ratios $<1$ indicate higher outdoor counts. In general, summer ratios were lower than winter reflecting the substantially higher spore levels prevailing out-of-doors in summer. Air conditioned (AC) libraries had lower ratios than conventionally ventilated (CV) libraries. Sign test comparisons between library spore counts and same day outdoor counts are also presented in Table 3; all such comparisons in AC libraries yielded significant differences. CV library spore counts also were significantly lower than corresponding outdoor counts overall and for the group of summer samples; in winter, the generally lower non-activity indoor levels did not differ significantly from those out-of-doors. In comparisons between library stacks and areas without book storage taken in the same building on the same day, relative spore counts did not differ significantly by sign test (data not shown). Activity/nonactivity ratios are presented in Table 4. Activity more than doubled spore levels both in summer and winter, and these increases were greatest in CV libraries.

The 20 taxa encountered on 2 or more plates are presented with frequency of recovery in Table 5 . In ambient air samples (nonactivity), Aspergillus fumigatus and $A$. niger were isolated more frequently indoors than out. $A$. versicolor, Arthrinium, Paecilomyces, Cladosporium oxysporum, and Trichoderma were isolated only indoors. Alternaria, Aureobasidium, and Epicoccum were isolated more frequently outdoors than in library interiors. Frequency of recovery on paper agar was higher than on Malt (comparing activity paper with activity Malt) for Alternaria, Epicoccum, Pithomyces, and Fusarium. Recovery on paper equalled that on Malt for Aspergillus niger, Cladosporium 
cladosporioides, and Trichoderma. Alternaria, A. niger, Aureobasidium, and Epicoccum frequencies on Malt were more than doubled by activity. Mean spores $/ \mathrm{M}^{3}$ for these same taxa were also more than double (Table 6). Indoor mean spore levels of A. niger, Paecilomyces, and Penicillium were approximately equal summer and winter. Spore levels for remaining taxa were reduced in the winter within libraries.

\section{Discussion}

Indoor levels of viable fungus spores in the University of Michigan libraries studied were moderately low when compared to counts for other types of local interiors (6) as well as to concurrent outdoor counts (Table 2). Indoor/ outdoor ratios (Table 3) range from 0.06 to 1.58 with in overall average in an 'undisturbed' library of 0.36 . In other words, the indoor levels of viable particles were about $1 / 3$ those out-of-doors. It should be reemphasized that viable sampling methods do not accurately reflect actual spore concentrations, but rather indicate trends. Accordingly, overall outdoor levels may have been even higher compared to indoor concentrations, since the error in viable sampling varies directly with spore levels (3).

Activity (manipulating the books) increased indoor spore levels (Table 2) and, secondarily, decreased indoor/ outdoor ratios (but usually did not raise indoor levels to equal those outdoors). Theoverall activity/nonactivity ratio for total sampling effort was 2.4 (i.e., spore levels were increased with activity 2.4 times). Summer ratios were slightly lower than in winter, probably reflecting higher ambient summer spore levels. The increase in particle recovery with activity was due either to refloatation of settled-out spores or primary dispersion of spores growing on the disturbed substrates. We observed very few cases of visible mold growth on books and none on other surfaces. Exceptions were in Clements library, on very old, rare books and in the Bureau of Government library where a pipe had broken and had soaked a few books. The pipe had been repaired and the books dried before we sampled, but the damaged books bore many mold colonies from which we isolated several taxa. We were unable to isolate viable mold spores from the Clements' books. The colonies on the books we examined appeared to have followed water damage that, probably, had occurred long before the books were added to the library. These nonviable spores would not have been detected by our sampling methods, but might have contributed to the air spora of allergic significance for sensitive persons.
One characteristic of the libraries that appears to influence spore concentrations is the type of ventilation and cooling system present. Indoor/outdoor ratios for $\mathrm{AC}$ libraries were lower than for CV libraries, and sign test comparisons indicated significantly lower spore levels in AC libraries when compared to outdoor levels. In $\mathrm{CV}$ libraries, on the other hand, differences between indoor and outdoor levels were significant by sign test only for year round and summer nonactivity samples. In two cases (year round activity and winter activity) indoor spore levels in CV libraries actually exceeded outdoor counts. Air conditioning also affected activity/nonactivity ratios. AC ratios were between 1.0 and 2.0 while $\mathrm{CV}$ ratios were between 3 and 4 . AC effects carried over into the winter. Apparently air conditioning limits spore access to interior situations and, therefore, reduces spore levels in dust deposits throughout the year. We assume that air temperature is important primarily in permitting windows of $\mathrm{AC}$ buildings to remain closed continuously thereby excluding outdoor particle clouds. For example, Public Health, a centrally AC library with no movable windows had by far the lowest counts both summer and winter; whereas Clements, with central AC installed after the library was in operation had low summer counts when windows remained closed but elevated counts at other times when windows were occasionally opened. Other factors such as age of building and mean age of books may also have contributed to the differences observed. The elevated nonactivity levels in the AC Phoenix library may reflect (the) excessive disturbance (moving of book collections) that occurred during the period of sample collections.

The fungus taxa recovered in libraries were generally similar to those collected out-of-doors (Table 5). The only taxa that were clearly recovered more frequently indoors than out were $A$. fumigatus (nonactivity) and $A$. niger, C. herbarum, Epicoccum spp and possibly Penicillium, (all associated with activity). Indoor/outdoor prevalence estimates cannot be made for taxa absent from outdoor collections and present only at low levels indoors, since unequal sampling periods (in some cases, 30 sec outdoors vs $10 \mathrm{~min}$ indoors) might account for certain of these disparities in occurrence. However, mean indoor levels of Penicillium spores were higher in winter than in summer in spite of lower winter outdoor levels, suggesting an interior source for these particles of Penicillium.

The experiments with filter paper agar were designed to detect fungi adapted to utilize book paper as a carbon source. Alternaria spp, Aspergillus niger, Cladosporium cladosporioides, Epicoccum, Fusarium, Pithomyces, and 
Trichoderma all were recovered at least as frequently on paper as on Malt media and, assuming adequate moisture and no interfering substances, should be able to grow on book paper. Alternaria, Epicoccum, and Pithomyces sporulated more abundantly on paper than on Malt agar. This, and the fact that levels of these taxa more than doubled when the books were actively used, suggest that specific library substrates may exist for some of these taxa.

Activity also substantially increased recoveries of Aspergillus niger and Aureobasidium particles, taxa which, with Alternaria and Epicoccum species, have thick spore walls that may promote viability in dust. By contrast, emanations of Cladosporium and Penicillium species, although the most abundant types in undisturbed library air, were only minimally increased after activity. These observations imply that, even in interior situations, the composition of air spora and of fungus particles in dispersable dust may differ perceptibly. However, in neither of these niches was a qualitatively unique library mycoflora evident. Furthermore, overall fungus levels within these interiors were only moderate by domestic standards suggesting other sources for library-based respiratory symptoms.

\section{References}

1. Aas, K. 1972. The allergic child. Springfield, Ill., Chas. C. Thomas.

2. Andersen, A. A. 1958. A new sampler for the collection, sizing, and enumeration of viable airborne particles. J. Bacteriol. $76: 471-484$.

3. Burge, H., J. Boise \& W. Solomon. 1977. Comparative recoveries of airborne fungus spores by viable and non-viable modes of volumetric collection. Mycopathologia $61: 27-33$.

4. Ellis, M. B. 1971. Dematiaceous Hyphomycetes. Commonwealth Agricultural Bureaux, Kew, U. K.

5. Raper, K. B. \& D. I. Fennell. 1965. The genus Aspergillus. Baltimore, The Williams and Wilkins Co.

6. Solomon, W. R. 1976. A volumetric study of winter fungus prevalence in the air of midwestern homes. J. Allergy \& Clin. Immunol. 57: 46-55.

7. Solomon, W. R. \& J. A. Gilliam. 1970. A modified application of the Andersen sampler to the study of airborne fungus particles. J. Allergy 45: 1-13. 